\section{What users actually do: a study of service-seeking behaviour in an academic library}

\section{Kathryn Ray, Michael Heine and Ian Winkworth}

\section{The Authors}

The authors all work at the University of Northumbria at Newcastle

E-mail: kathryn.ray@unn.ac.uk

Kathryn Ray is Research Assistant, School of Information Studies

Michael Heine is Principal Lecturer, School of Information Studies

Ian Winkworth is Director of Information Services

\section{The Context}

This research concept was first publicised at the Third Northumbria International Conference on Performance Measurement in August 1999. It was discussed at an informal workshop at Northumbria University in December 1999 - where the desirability of more sub-categories was highlighted. This article is presented here (i) for its intrinsic interest and (ii) because the authors wish to encourage researchers to take this methodology further in research projects elsewhere. (EDITOR)

\begin{abstract}
This article describes what is believed to be an innovative methodology for capturing the patterns and sequence of users' information service-seeking behaviour in one academic institution. The article outlines the thinking behind and development of this methodology; its application in terms of collecting data; and highlights the general results that emerged.
\end{abstract}

\section{Introduction}

This project was undertaken by the School of Information Studies and the Department of Information Services at the University of Northumbria at Newcastle (UNN) between September 1998 and June 1999. It was motivated by a previous study of the physical movements of users within a public library described by MacGregor Smith and Rouse (1979). It was also influenced by survey work undertaken in the 1970s by the Cambridge Library Management Research Unit (Seymour \& Schofield, 1973) of user behaviour at card catalogues in several UK academic libraries, where intended actions which would be taken following perceived or actual failure in that service were surveyed.

Libraries already collect statistics in respect of the volume of use, success rates or user satisfaction of individual services for users. To determine how users group their use of services in responding to a particular need this present research focuses on users' behaviour as characterized by sequences of service use. This is in contrast to the two previously mentioned studies, which focused respectively on physical movement within a public library and the use of one particular service.

\section{Project aim and objectives}

The aim of the project was to investigate the applicability and usefulness of a methodology for improving understanding of student service-seeking behaviour in academic libraries, with a view to developing that methodology so as to assist its applicability to any group of information services.

The objectives were:

- To devise and pilot a methodology

- To develop a methodology that is portable, so it can be used in any academic library and possibly other kinds of library

- To clarify in a conceptual way the sequential patterns of use of a library, so that both print and electronic services are covered.

- To investigate how the data obtained by applying such a methodology can be usefully analysed 
This research project was interested in developing a methodology that would capture:

- the number of different types of distinct service use, evident during a users' visit to the library. For example what percentages of users ask the advice of staff before choosing to identify documents.

- the proportion of usage of a single type of service, for example the use of a CD-ROM to identify documents matching some criteria

- the overall pattern of usage, for example, OPAC use and shelf-access use are each separately of interest, but the order in which these two types of usage are exercised was primarily of interest

- the effect of "user status" on service use, for example subject studied.

\section{Methodology}

Fundamental to this project was the development of a set of service categories labeled as S1, S2, S3 etc. A sequence of accesses to services in these categories can be defined by following a trail within these services. Individual episodes of use were then characterised as follows:
Library \& Information Research News (LIRN) Volume 24 - Number 76 - Spring 2000

User 1: S2, S4, S3, S1

User 2: 57

The first user accessed service S2 then accessed service S4, then S3 and finally S1, while the second user only accessed S7.

A schedule of categories was used to determine the users' service-seeking behaviour. This was devised in the first instance by the project team influenced to some extent by existing categories used in UK work on library performance (including Brophy and Wynne, 1997 and Winkworth, 1999). These initial categories were revised following both consultation with professional staff in Information Services at UNN and two pilot studies. The pilot studies each took place with 20 students.

The schedule of categories has two levels of service. This recognizes five levels of general service that are further broken down into 10 more specific service categories (see Figure 1).

\begin{tabular}{|l|l|l|l|}
\hline Code & Service Category & Code & Service sub-category \\
\hline 1 & $\begin{array}{l}\text { The provision of information about } \\
\text { documents }\end{array}$ & 1.1 & $\begin{array}{l}\text { The provision of means permitting the } \\
\text { identification of documents that match some } \\
\text { search specification }\end{array}$ \\
\hline & & 1.2 & $\begin{array}{l}\text { The provision of means for identifying local } \\
\text { holdings of known documents, and/or their } \\
\text { issue states }\end{array}$ \\
\hline 2 & $\begin{array}{l}\text { The provision of direct access to specific } \\
\text { (known) documents prior to fuller use }\end{array}$ & 2.1 & $\begin{array}{l}\text { The provision of one or more collections } \\
\text { local holdings of known documents and/or } \\
\text { their issue states } \\
\text { permitting the retrieval of specific documents } \\
\text { prior to use }\end{array}$ \\
\hline & & 2.2 & $\begin{array}{l}\text { Services supporting deferred use of known } \\
\text { documents by the user }\end{array}$ \\
\hline 3 & Support for immediate document study & 2.3 & Services supporting return of lent documents \\
\hline 4 & Advice giving and user education & 4.1 & The provision of study facilities \\
\hline & & 4.2 & Factual advice giving \\
\hline 5 & Utility Services & 5.1 & $\begin{array}{l}\text { The library provides for meetings, } \\
\text { conferencing, e-mailing, document production } \\
\text { using PC's, refreshment facilities, and sales of } \\
\text { study materials. }\end{array}$ \\
\hline
\end{tabular}

Figure 1 


\section{Data collection}

Interviews were undertaken with students between January and March 1999. The survey took place in two libraries in one university both to capture data per se and to provide an initial test of portability in the methodology. Both libraries offer similar services but support different teaching departments. 157 interviews were undertaken in one site library while 152 were undertaken in the other site library, constituting a sample population of 309 .

Interviewees were chosen on a "next-in-line" basis and were conducted at various times of the day as students left the library in order to capture data on the complete sequence of service uses during that
Library \& Information Research News (LIRN) Volume 24 - Number 76 - Spring 2000

visit. Incentives were not used to encourage student participation, however the refusal rate was relatively low. Of those asked to participate, $23 \%$ declined, the main reason provided being lack of time.

Interviews with students were based upon the earlier mentioned schedule of categories. To facilitate greater understanding, the schedule was adapted into a pro forma as shown in Figure 2. Students service-seeking patterns were recorded directly onto these forms by means of directed lines.

Date

Coach Lane

Time City Campus

\begin{tabular}{|l|l|}
\hline 1.1 & $\begin{array}{l}\text { Ifentify documents when know subject/author/class. (OPAC, CD-ROM, on-line, web, printed, } \\
\text { br wsing by class) }\end{array}$ \\
\hline 1.2 & Identify local holdings of known documents. (OPAC, CD-ROM, p int, catalogue) and issue states. \\
\hline 1.3 & Identify non-local holdings of known documents (BUBL, Web, C -ROM) and issue states \\
\hline 2.1 & $\begin{array}{l}\text { Get/look at known book } \\
\text { Look at electronic information prior to decision to use later }\end{array}$ \\
\hline 2.2 & Deferred use (lending, renewal, photocopying, reservation, ILL, \\
\hline 2.3 & Return material \\
\hline 3 & $\begin{array}{l}\text { Provision of study facilities (chairs, carrels, web clients, desks) to townloading web pages) } \\
\text { information sources }\end{array}$ \\
\hline 4.1 & Factual advice \\
\hline 4.2 & Professional advice \\
\hline 5 & $\begin{array}{l}\text { Utility Services } \\
\text { (Word process; meet others; coffee etc) }\end{array}$ \\
\hline EXIT LIBRAR
\end{tabular}

Subject

Some "looping" of specific services within a particular service category took place. 
What users actually do Kathryn Ray et al.

Figure 2 records library usage as follows:

1.1 The student identifies documents when the subject, class or author is known. This could be browsing the shelves of the library or by using electronic resources. For this action to be understood the interviewer identified in detail what particular service the student actually used however, for the purpose of this project it was sufficient to indicate only the category.

1.1 The student identifies documents when the subject, class or author is known. This action may have been identical to the previous action, or a document may have been identified by a different method

1.1 The student identifies documents when the subject, class or author is known. As above

2.1 The student either retrieves or looks at a known book or uses electronic information resources to identify material prior to use

3 The student then uses the study facilities available to study locally held or non-local information sources

2.2 The student then decides to defer his/her use of the material so either borrows, renews, reserves, photocopies, prints or down loads the material.

5 Utility services. The student has decided to use the word processor, meet up with friends, or go for refreshments (still within the library building)

100 The student leaves the library.

This condensed pro forma of Figure 1 was an essential tool in the project as categorising student's responses was particularly difficult at the time of the interview.

Each interviewee was asked their subject of study. The categorisation scheme used by the Higher Education Funding Council for England (HEFCE, 1997) was used to classify courses. This has 34 subject categories such as Geography, Nursing and paramedical studies, Humanities and Education (HEFCE, 1997).
Library \& Information Research News (LIRN) Volume 24 - Number 76 - Spring 2000

In order to minimise bias, where possible, the researcher followed a previously determined script when interviewing students. This did not prove possible in all cases. In order to achieve a true reflection of service pattern it was necessary to probe deeper and respond to each individual.

This individual probing was essential because of a number of factors:

- It became evident that students encountered difficulty recalling in sufficient detail the searching tactics they employed while searching electronic resources. For example they were able to recall the topic they were searching for, but found difficulty remembering the process they had undertaken to find the information that was required for this research.

- A number of students were unable to recall in detail their actual route through using the OPAC. For example, their immediate response was to say, "searched for a book checking the OPAC". More detail was required but they were often unable to recall whether they had undertaken a subject, author or title search and at what point they were either successful of accepted defeat!

- Students found difficulty remembering their exact pattern of use within the library. A number would state that they had looked at the OPAC and then moved to the issue desk to borrow their books without referring to physically retrieving these books from the open access shelves.

- Students appear to think physically rather than conceptually, which was the higher level of service use we wanted to capture. They would present a physical tour around the library rather than what they did at each service. They would state that they had "used the database to look up some current publications" and then gone "to Floor 6 to find some appropriate articles". For the purposes of this research it was essential to determine what they actually did while using the database to prevent only a physical tour of the library emerging.

However, with effective probing, this method proved particularly effective in collecting a large amount of data in a relatively short period of time. 


\section{Data Analysis}

The codes for the service categories used by each respondent were entered onto a data file containing a row for each respondent. A C++ programme was written to analyse these data yielding:

- the number of service categories accessed

- the transition frequencies from one service category to every other service

- the subject category of student's course and/or library used.

One of the predominant methods of analysing the data in this project was through the use of transition frequency tables. This is one way of analysing the sequences of service-use to provide an overall view of service-use behaviour

\begin{tabular}{|l|l|l|l|l|}
\hline Start & 17 & 4 & 1 & $\ldots$ \\
\hline$\ldots$ & S1 & 28 & 4 & $\ldots$ \\
\hline$\ldots$ & 41 & S2 & 51 & $\ldots$ \\
\hline$\ldots$ & 15 & 35 & S3 & $\ldots$ \\
\hline$\ldots$ & $\ldots$ & $\ldots$ & $\ldots$ & $\ldots$ \\
\hline
\end{tabular}

Figure 3

The service categories are recorded in the diagonal cells of the table. The other cells record the number of transitions between pairs of services to the other, with rows picking up frequency of transition from a particular service and columns doing so for frequency of transition to a given service.

Figure 3 translates as:

17 students on entering the library went immediately to service $\mathbf{S 1}$

4 students went immediately to service $\mathbf{S 2}$

28 students used service $\mathbf{S} \mathbf{2}$ immediately after service $\mathbf{S 1}$

51 students used service $\mathbf{S 3}$ immediately after service $\mathbf{S 2}$;

15 students used service $\mathbf{S} \mathbf{1}$ immediately after service $\mathbf{S 3}$

\section{Results}

Although the sample was small and constitutes students from only two libraries in one academic institution the results provide some interesting features that may be useful to system managers. This section will provide a brief synopsis of the general results accumulated from this project.

\section{Sequences of service-use}

A transition table data, using the more general schedule of service categories, is shown in Figure 4. The 0 in the top left hand cell refers to the start of the users' visit while the 100 refers to the end of the visit.

\begin{tabular}{|c|c|c|c|c|c|c|c|c|}
\hline & & & & & & & & $\begin{array}{l}\text { Row } \\
\text { sums }\end{array}$ \\
\hline & 0 & 84 & 163 & 14 & 5 & 43 & 0 & 309 \\
\hline & $*$ & S1 & 98 & 9 & 0 & 4 & 3 & 114 \\
\hline & $*$ & 17 & S2 & 104 & 3 & 51 & 149 & 324 \\
\hline & $*$ & 4 & 46 & S3 & 3 & 22 & 70 & 145 \\
\hline & $*$ & 5 & 6 & 0 & S4 & 0 & 0 & 11 \\
\hline & $*$ & 4 & 11 & 18 & 0 & S5 & 87 & 120 \\
\hline & $*$ & $*$ & $*$ & $*$ & $*$ & $*$ & 100 & $*$ \\
\hline $\begin{array}{l}\text { Column } \\
\text { sums }\end{array}$ & $*$ & 114 & 324 & 145 & 11 & 120 & 309 & \\
\hline
\end{tabular}

Figure 4: Transition frequencies (both libraries) 
Examples of interpretative statements drawn from Figure 4 are:

- 84 students on entering the library went immediately to service $\mathbf{S} 1$ (provision of information about documents)

- 163 students on entering the library went immediately to service $\mathbf{S} 2$ (provision of direct access to specific documents prior to fuller use)
- 149 students left the library after service $\mathbf{S} \mathbf{2}$

- 114 students accessed service $\mathbf{S} 1$ (provision of information about documents)

- 145 students accessed service S3 (support for immediate document study)

- 11 students accessed service $\mathbf{S 4}$ (advice giving and user education)

Figures 5 and 6 demonstrate sequences of service-use within the two libraries.

\begin{tabular}{|c|c|c|c|c|c|c|c|c|}
\hline & & & & & & & & $\begin{array}{l}\text { Row } \\
\text { sums }\end{array}$ \\
\hline & 0 & 35 & 85 & 6 & 3 & 7 & 0 & 136 \\
\hline & $*$ & S1 & 40 & 3 & 0 & 2 & 0 & 45 \\
\hline & $*$ & 5 & S2 & 53 & 2 & 16 & 81 & 157 \\
\hline & $*$ & 1 & 22 & S3 & 3 & 8 & 37 & 71 \\
\hline & $*$ & 3 & 5 & 0 & S4 & 0 & 0 & 8 \\
\hline & $*$ & 1 & 5 & 9 & 0 & S5 & 18 & 33 \\
\hline & $*$ & $*$ & $*$ & $*$ & $*$ & $*$ & 100 & $*$ \\
\hline $\begin{array}{l}\text { Column } \\
\text { sums }\end{array}$ & $*$ & 45 & 157 & 71 & 8 & 33 & 136 & \\
\hline
\end{tabular}

Figure 5: Transition frequencies (Library No. 1)

\begin{tabular}{|c|c|c|c|c|c|c|c|c|}
\hline & & & & & & & & $\begin{array}{l}\text { Row } \\
\text { sums }\end{array}$ \\
\hline & 0 & 49 & 78 & 8 & 2 & 2 & 0 & 139 \\
\hline & $*$ & S1 & 58 & 6 & 0 & 2 & 3 & 69 \\
\hline & $*$ & 12 & $\mathrm{~S} 2$ & 51 & 1 & 35 & 68 & 167 \\
\hline & $*$ & 3 & 24 & S3 & 0 & 14 & 33 & 74 \\
\hline & $*$ & 2 & 1 & 0 & S4 & 0 & 0 & 3 \\
\hline & $*$ & 3 & 6 & 9 & 0 & S5 & 1 & 53 \\
\hline & $*$ & $*$ & $*$ & $*$ & $*$ & $*$ & 100 & $*$ \\
\hline $\begin{array}{l}\text { Column } \\
\text { sums }\end{array}$ & $*$ & 69 & 167 & 74 & 3 & 53 & 139 & \\
\hline
\end{tabular}

Figure 6: Transition frequencies (Library No. 2) 
Summary of Figure 4 and Figure 5:

The tables suggest that the pattern of service use is broadly similar within both libraries.

Number of services accessed

\begin{tabular}{|c|l|}
\hline $\begin{array}{l}\text { Number of } \\
\text { services accessed } \\
\text { during the visit }\end{array}$ & $\begin{array}{l}\text { Number of } \\
\text { visits }\end{array}$ \\
\hline 1 & 88 \\
\hline 2 & 81 \\
\hline 3 & 47 \\
\hline 4 & 22 \\
\hline 5 & 25 \\
\hline 6 & 9 \\
\hline 7 & 2 \\
\hline 8 & 1 \\
\hline
\end{tabular}

Figure 7

Figure 7 shows the number of visits where the students accessed at least one information service.

\section{Summary of Figure 7}

- The most frequent number of service accesses within a visit was 1

- One student accessed eight services

\section{Average number of service category accesses}

Figure 8 highlights the mean number of service category accesses for the entire sample and for the various groups within the sample. (These figures are based on visits involving the use of at least one information service)

\begin{tabular}{|l|l|}
\hline Sample of visits & Mean \\
\hline All students, both libraries & 2.47 \\
\hline Library No. 1 students & 2.31 \\
\hline Library No. 2 students & 2.63 \\
\hline $\begin{array}{l}\text { Nursing and paramedical students } \\
\text { ( } \mathrm{n}=30)\end{array}$ & 2.33 \\
\hline Biosciences students $(\mathrm{n}=44)$ & 2.46 \\
\hline Humanities students $(\mathrm{n}=47$ & 2.72 \\
\hline Education students $(\mathrm{n}=41)$ & 1.88 \\
\hline
\end{tabular}

Figure 8

\section{Summary of Figure 8}

Within the sample of visits surveyed:

- Humanities students access more services than Education students

- Students using library No. 2 access more services than students using library No. 1

- Subject studied affects the number of services accessed.

\section{General summary of results}

- on average 2.5 types of service categories are accessed by a student on a single visit

- $22 \%$ of students use the catalogue first

- of the $22 \%$ of students, $56 \%$ of these then check issue status.

- less than $1 \%$ of visits entail use of the advice services, either professional or non-professional.

- $7 \%$ of the students included in the sample population use only 'utilities' (did not use any information service)

- $49 \%$ of the visits involved a catalogue search

- $47 \%$ of the sample used study facilities

- there were emerging differences between students studying particular subjects. Humanities students use more services (2.72) while Education students use less services (1.88) on each visit to the library on the evidence of the sample.

- the most popular service accessed immediately after entering the library was $\mathbf{S 2}$ (provision of direct access to specific documents prior to fuller use)

- the least popular service accessed immediately after entering the library was $\mathbf{S 4}$ (advice giving and user education)

\section{Conclusion}

This small-scale research project has provided a number of positive outcomes including the design of an effective data collection method, and relevant analytical and presentational tools. The project highlights a number of problems that include the level of detail in the classification scheme becoming too detailed for the responses from the students. Despite these problems the project did highlight that this methodology can be used to collect valuable service access data that would allow system managers to gain a deeper appreciation of serviceuse patterns. 
NOTE - The authors would be pleased to generate and return transition tables and related output on behalf of persons interested in undertaking surveys of the type described, provided data files are sent to them in an appropriate format. Confidentiality would of course be respected.

\section{References}

Brophy, P. and Wynne, P. (1997) Management information systems and performance measurement for the electronic library. Centre for Research in Library and Information Management, Manchester Metropolitan University,

MacGregor Smith and Rouse (1979) Application of queuing network models to optimization of resource allocation within libraries, Journal of the American Society for Information Science 30, 250-263

Seymour, C.A \& Schofield, J. L. (1973). Measuring reader failure at the catalogue. Library Resources and Technical Services, 17, 6-24.

Heine, M.H.,Winkworth, I., and Ray, K. (1999) Modeling service seeking behaviour in an academic library: a methodology and its application Journal of Academic Librarianship [in press]

Winkworth, I., Heine, M.H., and Ray, K. Measuring users' service-seeking behaviour. Paper presented at the 3rd Northumbria International Conference on Performance Measurement in Libraries and Information Services: "Value and Impact", Longhirst, Northumberland, 27-3I August 1999 published Information North, Newcastle upon Tyne, 2000

Higher Education Funding Council for England (1997) Assigning Departments to Academic Cost Centres: Annexe A. http://www.niss.ac.uk/education/hefce/pub97/97_25.html \#anna

Winkworth, I.R. (1999) "Performance measurement and performance indicators" in Jenkins, C. and Morley, M. eds. Collection Management in Academic Libraries, 2nd ed.

Aldershot: Gower p.7|-105 